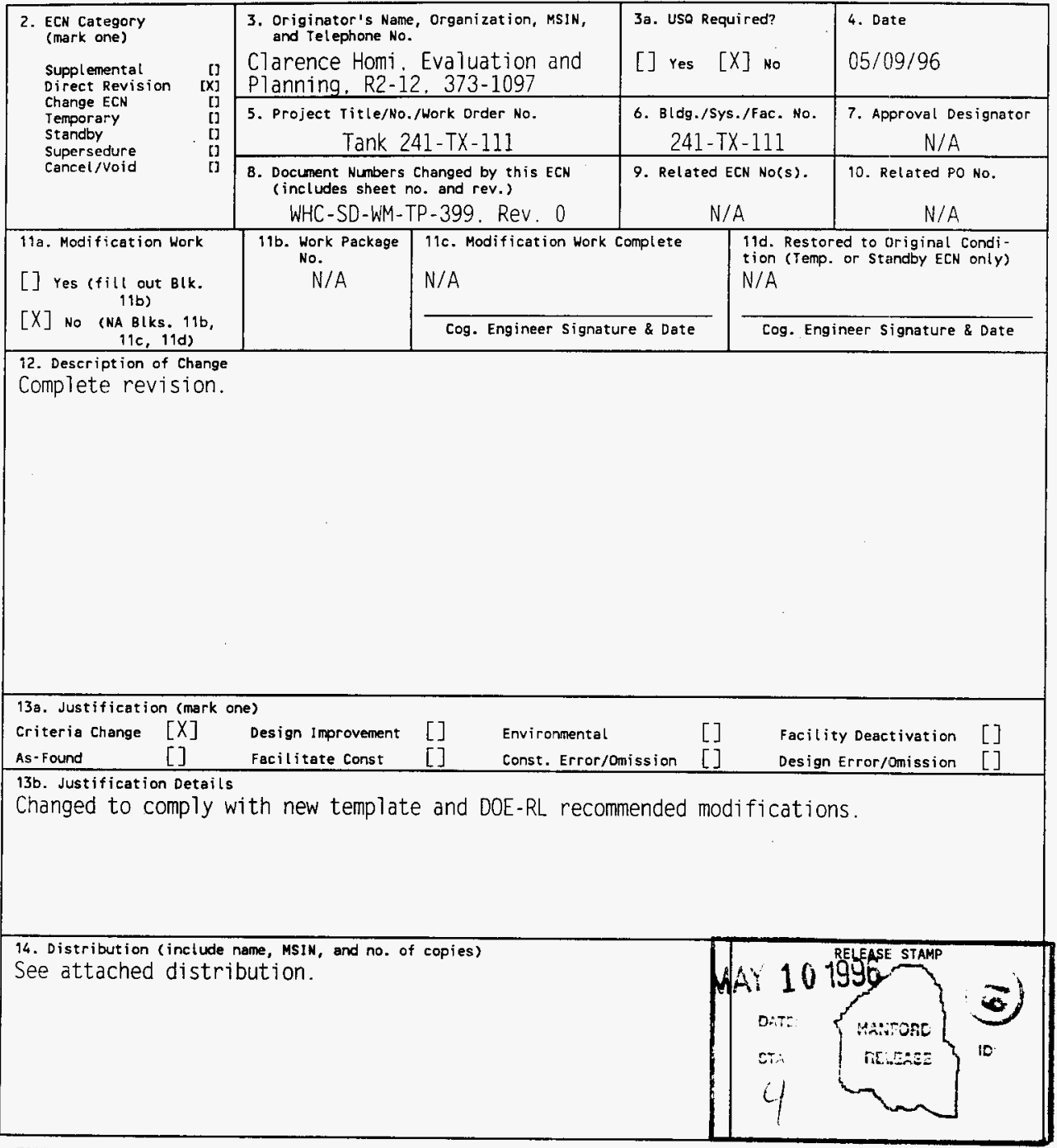




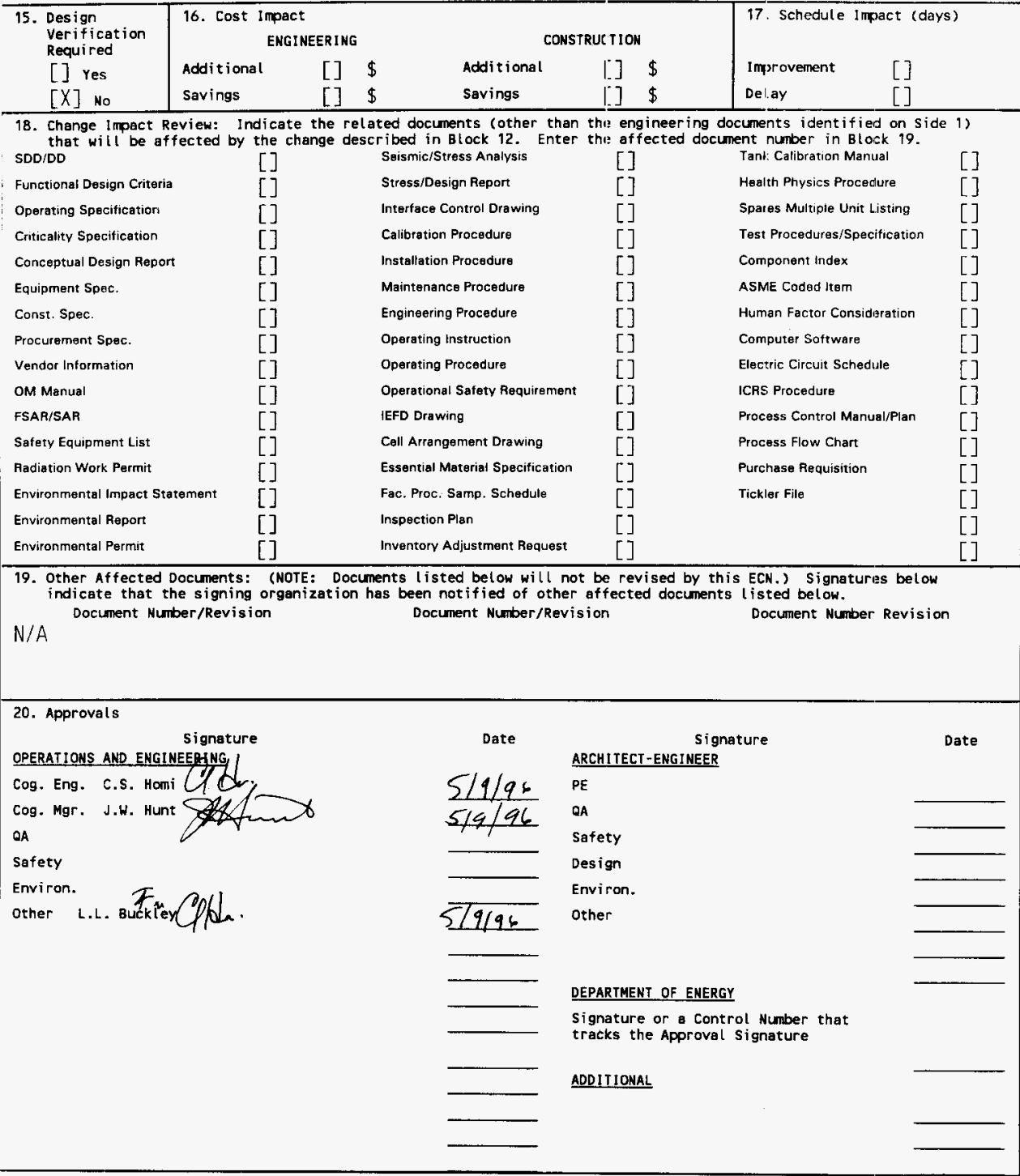




\section{Tank 241-TX-111 Tank Characterization Plan}

C. S. Homi

Westinghouse Hanford Company. Richland. WA 99352

U.S. Department of Energy Contract DE-AC06-87RL10930

EDT/ECN: $\quad$ ECN-631568 UC: 2070

Org Code: 79200

B\&R Code: EW 3120074 Total Pages: 9

Key Words: Characterization. General Safety Issues. Specific Safety Issues, Information Requirements. Schedule

Abstract: This document is a plan that identifies the information needed to address relevant issues concerning short-term and long-term storage and long-term management of single-she11 tank 241-TX-111.

TRADEMARK DISCLAIMER. Reference herein to any specific comercial product, process, or seirvice by trade name, trademark, manufacturer, or otherwise, does not necessarily constitute or imply its endorsement, recomendation, or favoring by the United states Goverment or any agency thereof or its contractors or subcontractors.

Printed in the United States of America. To obtain copies of this document, contact: UHC/BCS Document Control Services, P.O. Box 1970, Mailstop H6-08, Richland HA 99352, Phone (509) 372-2420; Fax (509) 376-4989.
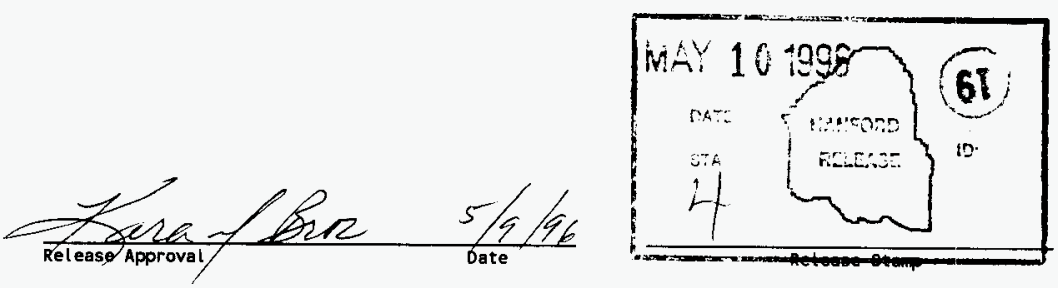

Approved for Public Release 


\section{RECORD OF REVISION}

(1) Document Number

WHC-SD-WM-TP-399

Page 1

(2) Title

Tank 241-TX-111 Tank Characterization Plan

CHAHEE CONTROL RECORD

\begin{tabular}{|c|c|c|c|c|}
\hline \multirow{2}{*}{ (3) } & \multirow{2}{*}{ Revision } & \multirow{2}{*}{ (4) Description of Change - Replace, Add, and Delete Pages } & \multicolumn{2}{|c|}{ Authorized for Release } \\
\hline & & & (5) Cog. Engr. & (6) Cog. Mgr. \\
\hline & 0 & 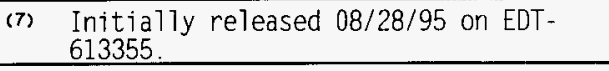 & C.S. Homi & S.J. Eberlein \\
\hline 3 & 1 & Incorporate per ECN-631568. & C.S. Homi & J.W. Hunt \\
\hline & & & & Hin $5 / 9 / 9$ \\
\hline & & & & \\
\hline & & & & 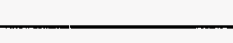 \\
\hline & & & & 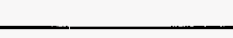 \\
\hline & & & & \\
\hline & & & & \\
\hline & & & & \\
\hline & & & & \\
\hline & & & & 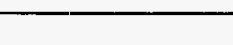 \\
\hline & & & & +2 \\
\hline & & & & \\
\hline & & & & \\
\hline & & & & \\
\hline & & & & \\
\hline & & & & \\
\hline & & & & \\
\hline & & & & \\
\hline & & - & & \\
\hline & & & & \\
\hline & & & & \\
\hline & & & & \\
\hline & & & & \\
\hline & & & & \\
\hline & & & & \\
\hline & & & & \\
\hline & & & & \\
\hline & & & & \\
\hline & & & & \\
\hline & & & & \\
\hline & & & & \\
\hline & & & & \\
\hline
\end{tabular}


WHC-SD-WM-TP-399

Revision 1

UC-2070

\section{Tank 241-TX-111 Tank Characterization Plan}

L. L. Buckley

Westinghouse Hanford Company

Date Published

May 1996
Prepared for the U.S. Department of Energy

Office of Environmental Restoration and

Waste Management

\section{(2.) Westinghouse}

P.O. Box 1970

Richland, Washington

Management and Operations Contractor for the

U.S. Department of Energy under Contract DE-AC06-87RL10930 
WHC-SD-WM-TP-399, REV 1

TABLE OF CONTENTS

1.0

INTRODUCTION

2.0

PROGRAM ELEMENTS REQUIRING INFORMATION FOR TANK 241-TX-111 . . . . I

2.1 GENERAL SAFETY ISSUES

2.2 SPECIFIC SAFETY ISSUES . . . . . . . . . . . . . . 2

2.2.1 Ferrocyanide .............. . 2

2.2 .2 Organic ................ . . 2

2.2 .3 High Heat ................. 2

2.2 .4 Flammable Gas ............... . . 2

2.2 .5 Vapor................. 2

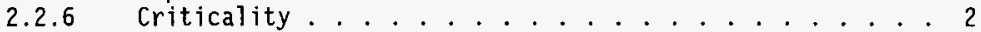

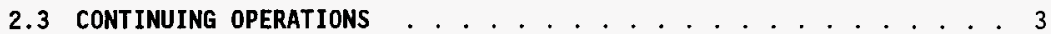

2.3.1 Compatibility/Stabilization .......... 3

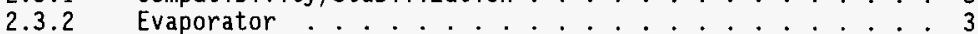

2.4 DOUBLE-SHELL TANK WASTE ANALYSIS PLAN . . . . . . . . . 3

2.5 DISPOSAL . . . . . . . . . . . . . . . . 3

2.5.1 Retrieval ................ 3

2.5.2 Pretreatment/Vitrification .......... 3

2.6 HISTORICAL MODEL EVALUATION . . . . . . . . . . 3

3.0 HOW INFORMATION WILL BE OBTAINED ............. 3

4.0 PRIORITY OF INFORMATION REQUIREMENTS . . . . . . . . . . . 4

5.0 WHEN INFORMATION WILL BE AVAILABLE ........... 4

6.0 REFERENCES ................. 5

\section{LIST OF TABLES}

4-1 Integrated DQO Requirements and Priorities......... 4 


\subsection{INTRODUCTION}

This Tank Characterization Plan (TCP) identifies the information needed to address relevant issues concerning short-term and long-term safe storage and long-term management of single-she11 tank 241-TX-111 (TX-111). It should be understood that the various needs and issues surrounding tank TX-111 are evolving as new information about the tank is uncovered. As a result of this progression, this TCP addresses only the issues that, to this date, have been identified. It is expected that deviations from this plan may occur as additional issues or needs arise which impact the management of TX-111. This TCP will be revised as necessary to reflect those changes or deviations. This plan reflects the best information available as of May 1996.

Tank TX-11l was constructed between 1947 and 1948 and was put into service in March 1950. Initially tank TX-111 received first cycle decontamination waste. Presently, the waste is classified as non-complexed. The tank is sound and was removed from service in 1977. Tank TX-111 is passively ventilated and was interim stabilized in April 1983 with intrusion prevention completed in August 1984 (Brevick et a1. 1995).

Tank TX-111 currently contains a total waste volume of $1,400 \mathrm{~kL}(370 \mathrm{kgal})$, which is equivalent to $360 \mathrm{~cm}$ (142 in) of waste as measured from the baseline of the tank (Hanton 1996).

This tank is not on any watch List.

Near-term sampling and analys is activities are focused on either verifying or changing the Watch List tank status, and identifying any new safety issues. Should any safety issues be identified, additional analysis will occur corsistent with the identified issue.

In addition to the resolution of the safety issues, it is intended that all tank waste will be subject to pretreatment and retrieval to prepare for final storage or disposal. Presently, these long-range plans have yet to be fully identified and are, therefore, not included in this document.

\subsection{PROGRAM ELEMENTS REQUIRING INFORMATION FOR TANK 241-TX-111}

This section identifies the various program elements, and identifies which of these programs require characterization data from tank TX-111.

\subsection{GENERAL SAFETY ISSUES}

The Tank Safety Screening Data Quality Objective (Dukelow et al. 1995) describes the sampling and analytical requirements that are used to screen waste tanks for unidentified safety issues. Analytical requirements for the safety screening of a tank are energetics, total alpha activity, moisture content, density and flammable gas concentration. 


\subsection{SPECIFIC SAFETY ISSUES}

\subsubsection{Ferrocyanide}

This tank is not on the Ferrocyanide Watch List; therefore, no information needs are currently identified for this program element.

\subsubsection{Organic}

This tank is not on the Organic watch List; therefore, no information needs are currently identified for this program element.

\subsubsection{High Heat}

This tank is not on the High Heat Watch List; therefore, no information needs are currently identified for this program element.

\subsubsection{Flammable Gas}

This tank is not on the Flammable Gas Watch List; therefore, no information needs are currently identified for this program element.

\subsubsection{Vapor}

A11 177 underground tanks must be vapor-sampled for organic solvent screening as per Recommendation 93-5 Implementation P7an (DOE-RL 1996). Some tanks may require additional vapor sampling due to other program needs. These tanks may be classified into four categories: (1) those tanks which are to be rotary mode core sampled (as a consequence of the rotary sampling system exhauster permit requirements); (2) tanks on the Organic or Ferrocyanide Watch Lists; (3) tanks in C farm; and (4) tank 241-BX-104, due to vapor exposure. Information needs must satisfy Data Quality Objectives for Tank Hazardous Vapor Safety Screening (Osborne and Buckley 1995), and for rotary mode only, Rotary Core Vapor Sampling Data Quality Objective (Price 1994), and Data Quality Objective for Regulatory Requirements for Hazardous and Radioactive Air Emissions Sampling and Analysis (Mulkey and Markillie 1995) as amended by Status of the Current Understanding of the Toxic Air Pollutants (TAPS) and Hanford Tank Farm Vapor Space Characterization; Recommended Path Forward and Justification for Cont inued RMCS Exhauster Operations (Laws 1996).

Tank TX-111 was vapor sampled in 0ctober 1995 in support of 0sborne et al. (1995).

\subsubsection{Criticality}

No information separate from that for the general safety issue of tank TX-111 are currently identified for this program element. However, if the general safety screening of tank TX-111 identifies a potential criticality concern, analyses for fissile materials and neutron sorbers and poisons will be performed as identified in the safety screening data quality objective. 
WHC-SD-WM-TP-399, REV 1

2.3 CONTINUING OPERATIONS

2.3.1 Compatibility/Stabilization

This section does not apply to tank TX-111.

\subsubsection{Evaporator}

This section does not apply to tank TX-111.

\subsection{DOUBLE-SHELL TANK WASTE ANALYSIS PLAN}

This section does not apply because tank TX-111 is a single-she1l tank.

\subsection{DISPOSAL}

\subsubsection{Retrieval}

Current retrieval needs (Bloom and Nguyen 1995) do not call for test samples to be taken from tank TX-111.

\subsubsection{Pretreatment/Vitrification}

Tank TX-111 has not been identified as a bounding tank for pretreatment/ disposa? process development strategy (Kupfer et a1. 1995). A17 tanks were prioritized using the pretreatment strategy in the Tank Waste Characterization Basis (Brown et a7. 1995) document and a portion of archive sample material could be used for pretreatment testing if available. The strategy does not require any specific analyses to be done on the samples.

\subsection{HISTORICAL MODEL EVALUATION}

Bounding tanks and data requirements for historical model evaluations are found in Historical Model Evaluation Data Requirements (Simpson and McCain 1995). Tank TX-111 has been identified as a primary bounding tank for the T2 salt cakewaste type. All single-shell tanks were prioritized in the Tank Waste Characterization Basis (Brown et al. 1995) document using the historical DQO.

\subsection{HOW INFORMATION WILL BE OBTAINED}

The number of samples required to characterize a tank is a function of waste heterogeneity and the desired confidence to make a correct decision. As directed by the safety screening DQO, if inadequate information exists to 
determine an appropriate number of samples, two vertical profiles will be obtained. These vertical profiles may be obtained using core, auger (for shallow tanks), or grab samples. If analysis of these profiles reveals that additional profiles are necessary to meet data needs, more sample profiles will be requested. Prior to rotary sampling it is necessary to vapor sample the tank per the requirements of Rotary Core Vapor Sampling Data Quality objective (Price 1994).

\subsection{PRIORITY OF INFORMATION REQUIREMENTS}

Vapor sampling was completed in October 1995. Rotary mode core sampling is scheduled to begin in January 1997 (Stanton 1996). Refer to Table 4-1 for the current $D Q 0$ requirements and planned sampling and analytical requirements.

Table 4-1: Integrated DQO Requirements and Priorities

\begin{tabular}{||l|l|l|l||}
\hline $\begin{array}{l}\text { Sampling } \\
\text { Event }\end{array}$ & \multicolumn{1}{|c||}{ Applicable Issues } & Sampling Requirements* & Analytical Requirements \\
\hline $\begin{array}{l}\text { Rotary } \\
\text { Mode Core } \\
\text { Sampling }\end{array}$ & $\begin{array}{l}\text {-Safety Screening DQ0 } \\
\text {-Historical DQO }\end{array}$ & $\begin{array}{l}\text { Core samples from 2 } \\
\text { risers separated } \\
\text { radially to the } \\
\text { maximum extent } \\
\text { possible }\end{array}$ & $\begin{array}{l}\text { Energetics, Moisture, } \\
\text { Total alpha activity, } \\
\text { Density, Anions, Metals, } \\
\text { Radionuclides, Total } \\
\text { Organic Carbon }\end{array}$ \\
\hline $\begin{array}{l}\text { Vapor } \\
\text { Sampling } \\
\text { measurement }\end{array}$ & $\begin{array}{l}\text {-Organic Solvent Layer } \\
\text { 93-5 Vapor Issue } \\
\text {-Rotary Mode Sampling } \\
\text { DQD } \\
\text {-Hazardous Vapor DQ0 }\end{array}$ & $\begin{array}{l}\text { Steel canisters, } \\
\text { Triple Sorbent Traps, } \\
\text { Sorbent Trap Systems. }\end{array}$ & $\begin{array}{l}\text { Flammable Gas } \\
\text { Permanic Vapors }\end{array}$ \\
\hline
\end{tabular}

* Consult each applicable DQO in force at the time for sampling and analytical requirements.

\subsection{WHEN INFORMATION WILL BE AVAILABLE}

According to Stanton (1996) data are expected to be available from the rotary mode core sampling event for tank TX-111 in June 1997. This time may be altered if the sampling schedule changes. Data are available from the october 1995 vapor sampling. 


\section{WHC-SD-WM-TP-399, REV 1}

\subsection{REFERENCES}

Bloom, G. R. and Q. H. Nguyen, 1995, Characterization Data Needs for Development, Design and Operation of Retrieval Equipment Developed Through the Data Quality Objective Process, WHC-SD-WM-DQ0-008, Rev. 0, Westinghouse Hanford Company, Richland, Washington.

Brevick, C. H., L. A. Gaddis, and W. W. Pickett, 1995, Historical Tank Content Estimate for the Northwest Quadrant of the Hanford 200 East Areas, WHC-SD-WM-ER-352, Rev. 0, Westinghouse Hanford Company, Richland, Washington.

Brown, T. M., S. J. Eberlein, and T. J. Kunthara, 1995, Tank Waste Characterization Basis, WHC-SD-WM-TA-164, Rev. 1, Westinghouse Hanford Company, Richland, Washington.

DOE-RL, 1996, Recommendation 93-5 Implementation P7an, D0E/RL-94-0001, Rev. 1, U.S. Department of Energy, Richland, Washington.

Dukelow, G. T., J. W. Hunt, H. Babad, and J. E. Meacham, 1995, Tank Safety Screening Data Quality Objective, WHC-SD-WM-SP-004, Rev. 2, Richland, Washington.

Hanlon, B.M., 1996, Waste Tank Summary for Month Ending January 31, 1996, WHC-EP-0182-94, Westinghouse Hanford Company, Richland, Washington.

Kupfer, M. J., W. W. Schultz, and J. T. Slankas, 1995, Strategy for Sampling Hanford Site Tank Wastes for Development of Disposal Technology, WHC-SD-WM-TA-154, Rev. 1, Westinghouse Hanford Company, Richland, Washington.

Laws, G. L., 1996, Status of the Current Understanding of the Toxic Air Pollutants (TAPS) and Hanford Tank Farm Vapor Space Characterization; Recommended Path Forward and Just ification for Cont inued RMCS Exhauster Operations, (telephone conference memorandum, 01830-96-022, to Distribution, March 8) Westinghouse Hanford Company, Richland, Washington.

McDuffie, N. G., 1995, Flammable Gas Tank Safety Program: Data Requirements for Core Sample Analysis Developed Through the Data Quality Objectives Process, WHC-SD-WM-DQ0-004, Rev. 2, Westinghouse Hanford Company, Richland, Washington.

Mulkey, C.H., and K. D. Markillie, 1995, Data Quality Objective for Regulatory Requirements for Hazardous and Radioactive Air Emissions Sampling and Analysis, WHC-SD-WM-DQ0-021, Rev. 0, Westinghouse Hanford Company, Richland, Washington.

Osborne, J. W., and L. L. Buckley, 1995, Data Quality Objectives for Tank Hazardous Vapor Safety Screening, WHC-SD-WM-DQ0-002, Rev. 2, Westinghouse Hanford Company, Richland, Washington. 
Osborne, J. W., J. L. Huckaby, E. R. Hewitt, C. M. Anderson, D. D. Mahlum, B. A. Pulsipher, and J. Y. Young, 1995, Data Quality Objectives for Generic In-Tank Health and Safety Vapor Issue Resolution, WHC-SD-WM-DQ0-002, Rev. 2, Westinghouse Hanford, Richland, Washington.

Price, D. N., 1994, Rotary Core Vapor Sampling Data Quality Objective, WHC-SD-WM-SP-003, Rev. 0, Westinghouse Hanford Company, Richland, Washington.

Simpson, B. C., and D. J. McCain, 1995, Historical Model Evaluation Data Requirements, WHC-SD-WM-DQ0-018, Rev. OA, Westinghouse Hanford Company, Richland, Washington.

Stanton, G. A., 1996, Baseline Sampling Schedule, Change 96-02, (internal memo 75610-96-06, to Distribution, Apri1 17), Westinghouse Hanford Company, Richland, Washington. 


\begin{tabular}{|c|c|c|c|c|c|}
\hline \multicolumn{6}{|c|}{ DISTRIBUTION SHEET } \\
\hline \multirow{2}{*}{$\begin{array}{l}\text { To } \\
\text { Distribution }\end{array}$} & \multirow{2}{*}{\multicolumn{3}{|c|}{$\begin{array}{l}\text { From } \\
\text { Evaluation and Planning }\end{array}$}} & \multicolumn{2}{|l|}{ Page 1 of 1} \\
\hline & & & & \multicolumn{2}{|c|}{ Date $\quad 05 / 09 / 96$} \\
\hline \multicolumn{4}{|l|}{ Project Title/Work Order } & \multicolumn{2}{|l|}{ EDT No. $N / A$} \\
\hline \multicolumn{4}{|c|}{$\begin{array}{l}\text { WHC-SD-WM-TP-399. Rev. 1. "Tank 241-TX-111 Tank Characterization } \\
\text { Plan" }\end{array}$} & \multicolumn{2}{|c|}{ ECN No. ECN -631568} \\
\hline Name & MSIN & $\begin{array}{c}\text { Text } \\
\text { With } \\
\text { All } \\
\text { Attach }\end{array}$ & Text Only & $\begin{array}{l}\text { Attach./ } \\
\text { Appendix } \\
\text { Only }\end{array}$ & $\begin{array}{l}\text { EDT/ECN } \\
\text { Only }\end{array}$ \\
\hline
\end{tabular}

ONSITE

U. S. Department of Energy -

Richland Field Office

W. Liou

N. W. WiTl is

$\begin{array}{ll}\text { S7 }-54 & x \\ 57-54 & x\end{array}$

Westinghouse Hanford Company

L. L. Buckley

G. D. Forehand

C. S. Homi

Central Files

T.C.R.C.
R2 -12

S7-21

R2-12

A3- 88

R2-12

$x$
$x$

$$
x
$$

